\title{
CAUSAL RELATIONS IN ENGLISH NEWS MAGAZINE DISCOURSE: JOURNALISTS' AGE PERSPECTIVE
}

\author{
Iryna Danylchenko
}

\begin{abstract}
This paper reveals how journalists' age influences the linguistic representation of causal relations in English news magazine articles. Treating cause in a broad sense covering adverbials and clauses of reason, concession, purpose and result, the study finds that causal relations are scarce in the texts of young reporters. Unlike them, middle-aged authors' articles demonstrate a 17-per-cent-higher frequency of adverbials and clauses of reason, and older journalists' texts show a 12-per-cent rise in concessive clauses with the temporal concessive, comparative concessive, alternative concessive, conditional concessive and generalizing concessive relations. To account for these findings, I apply Talmy's (1985) force dynamics theory viewing cause as an interaction of entities concerning force and energy where one causes another. Given this theory, middle-aged journalists verbalise causal relations grounded in what I call energy transfer model with one moving entity causing another to move, and energy loss model where inactivity of one entity is due to blocking of the other entity. In older authors' articles, causal relations are represented by concessive clauses introduced by a range of conjunctions specifying concessive meaning: temporal concessive, comparative concessive, alternative concessive, conditional concessive and generalizing concessive.
\end{abstract}

\section{Keywords}

causal relations, news magazine discourse, journalists' age, reason clauses, adverbials of reason, concessive clauses, force dynamics, energy transfer model, energy loss model

\section{Introduction}

Causal relations broadly defined as an interaction of objects, events or situations in which the activity of one entity is understood as emerging or resulting from the influence of the other (Pander Maat \& Sanders 2001, Copley et al. 2015, Heil 2016: 128, Solstad \& Bott 2017) have been widely studied in linguistics within a number of trends. The 'descriptive' approach focuses primarily on the means of verbal representations of these relations concerning the use of lexical items such as causative verbs (Shibatani 1976: 3), prepositions, adverbials, and syntactic structures including adverbials, clauses and conjunctions linking them (Quirk et al. 1985: 1103). Drawing on the semantics of conjunctions introducing adverbial clauses, scholars differentiate direct and indirect causes covering not only the relations of reason but also adjacent meanings of explanation, 
justification, contrast, contingency, etc. (Quirk et al. 1985: 1105). Further within this approach, causal relations are classified into internal with inner forces such as person's desires, motives and emotional arousals serving as an impetus for actions, and external relations where forces from outside cause something to happen (Williams 1979: 104). The differentiation of cause types is represented in lexicon with the group of verbs which Levin and Rappaport (1995: 91) call internally caused such as laugh, speak, flash, shudder, etc., and externally caused denoting change of state (break, cook, etc.) and motion (move, roll, rotate, etc.).

The 'semantic' approach explains causal relations as links of propositions or their groups (Hollenbach 1975: 16). The meaning of causative verbs is taken into account for their role in propositions, which resulted in the development of the theory of the predicate-argument structure in terms of semantic roles (Fillmore 1977: 72) which finds that much of phrase structure is arranged around causal relations between events or event-like entities such as situations (Kemmer \& Verhagen 1994: 115). Drawing on the predicate-argument structure of sentences where verbs determine the presence and number of arguments and assign roles to them (Croft 2012) such as agent, patient, experiencer, possessor etc., causal constructions, i.e. form and meaning parings, are singled out (Goldberg 2010). With the constructionist turn, the semantic approach gives way to the 'cognitive' analysis of causal relations which states that the predicate-argument structure of a sentence is rooted in human cognition, and causal relations in language reflect the mechanisms of reasoning (Wolff et al. 2010, Neeleman \& van de Koot 2012). In this vein, causal relations are treated as derivative from an interaction of physical forces mutually affecting each other, which is spelt out by the forcedynamic theory proposed by Talmy (1985). It successfully expands to the forcedynamic analysis of modals (Sweetser 1990), accounts for the causal syntactic meanings (Martin \& Schafer 2014) and explains cognitive rhetorical effects creation (Potapenko 2016).

However, none of these three approaches - descriptive, semantic and cognitive - takes into account speakers with their individual parameters playing a role in expressing causal relations. While within the cognitive approach there are studies accounting for connections between syntactic structure and cognition (Dalbergenova et al. 2014: 233), elucidating the peculiarities of human conceptualisation of events and their causes (Chu 2004) and explaining speakers' involvement in establishing causal relations between events (Copley \& Harley 2015, Pander Maat \& Degand 2001), no research has demonstrated how speakers' parameters of age, gender, education, and social background contribute to verbalising causal relations in a broad sense. This paper is an attempt to redress this imbalance - its aim is to explore how authors' age influences the 
linguistic representation of causal relations in English. I hypothesise that their overall frequency will change with authors' age and different types of causes will be dominant in the articles of young, middle-aged and older authors because with time people change in every aspect of their personalities - physical, psychological, cognitive, social, etc. Consequently, causal relations fundamental to human cognition (Lakoff \& Johnson 1980, Gilquin 2010: 1) are likely to be verbalised differently. Thus, the study intends to answer the following questions:

1) How frequent are causal relations in the articles of young, middle-aged and older authors?

2) What types of causal relations dominate in the texts written by authors of different age?

3) What cognitive models account for the differences in verbalising causal relations by journalists of different age?

News magazine articles are taken as material for analysis because conveying information about recent events journalists interpret what is reported (Cotter 2010: 43) and identifying causal relations between events plays an essential role in this process. So, the novelty of this research consists in revealing the influence of authors' age on verbalisation of causal relations in news magazine articles.

The paper is structured in the following way. The outline of previous research into causal relations suggested in Section 1 will be developed in Section 2, accounting for their cognitive background. There, I will explain the method I adopt for this investigation - force dynamics. Section 3 will demonstrate how causal relations expressed in English news magazine discourse depend on journalists' age. In the concluding section, I will reflect on further investigations of speakers' parameters such as gender, social background, etc.

\section{Material and method}

Exploring authors' age influence on the verbalisation of causal relations in English news magazine discourse, I resort to the methodology consisting of three stages - classifying, cognitive and interpretational. The first stage consists in collecting the material for the research - articles written by young, middleaged and older journalists and singling out means of expressing causal relations. Cognitive stage concerns the analysis of causal relations with the application of the force dynamic method; at the interpretational stage, I discuss how the journalists' age accounts for different use of causal adverbials and clauses.

\subsection{Material}

The language corpus for this study is represented by the internet-based version of news magazine Newsweek (newsweek.com). I classified the selected 
articles into three groups according to the authors' age: 1) written by young journalists aged 26-36, 2) produced by middle-aged authors aged 40-56, and 3) created by older writers aged over 60 (Erikson \& Erikson 1998: 112-113). In this study, I left out the marginal age spectrum of 37-39 and 57-59, where adjacent age categories overlap.

The info about the journalists' age is available on their official websites, social media accounts on Facebook (facebook.com), Instagram (instagram.com), LinkedIn (linkedin.com) and Wikipedia category "Newsweek people" (en wikipedia.org), which features the bios of Newsweek's contributors.

I selected 90 articles from Newsweek published in 2009-2019: 30 of them written by young reporters, another 30 - by middle-aged authors, and the final 30 - by older journalists. All the articles were of equal size - 1,500-1,700 words each. Further, in these articles, I singled out causal adverbials and clauses that exemplify causal relations. The total sample is 299 causal adverbials and 367 clauses obtained from 90 articles. The collected data was analysed.

\subsection{Method}

I choose force dynamic methodology in this study because being a generalisation over the traditional notion of causative it disintegrates a situation into its constituents - the entity that causes something to happen and the one that is affected (Talmy 2000: 407). These entities enter the relations of force by performing such actions as (1) its exertion, (2) resistance to it, (3) overcoming of resistance, (4) blockage of the expression of force, and (5) removal of the blockage (ibid.: 409). Force dynamics reveals the relations between the entities through the opposition of the Agonist, i.e. the focal force, and the Antagonist directed against the former (ibid.: 410). Each of them is characterised by opposing internal tendencies: to motion or rest, or in more general terms, to activity or inactivity (ibid.: 413).

The theory of force dynamics is involved in explaining causal relations in news magazine articles where the Agonist and the Antagonist represent the participants of reported events. Extending the force dynamic approach to the structure of complex sentences, I take into account the basic models of force interaction accounting for the prototypical causal meanings and complex ones such as Langacker's billiard ball model with one moving entity causing another to move in a variety of different ways (Langacker 2008: 103).

The procedure of analysis of causal relations involves three stages. The firstidentifying - stage of analysis is singling out interacting entities - the Agonist and the Antagonist. The Agonist is usually indicated by a word in the focal position 
of the subject of a sentence; the Antagonist is expressed by a noun or pronoun within the adverbial or represented by the subject of adverbial clause:

Because of Trump, Jesus's hometown, Nazareth, is cancelling Christmas. (Newsweek, 14 December 2017)

Because the Iranian nuclear program's computers are not connected to the Internet, the worm couldn't have been introduced to them online. (Newsweek, 20 December 2010)

In the simple sentence in (1), Nazareth metonymically representing the authorities of the town enacts the role of the Agonist; Trump is the Antagonist signalled by the preposition because of introducing him. In the complex sentence in (2), the Agonist is the worm virus, and the Antagonist is designated by the subject of the adverbial clause the computers. Singling out interacting entities - the Agonist and the Antagonist - is important for analysing causal relations, since they reveal the cognitive background.

The second - interactional - stage of the analysis of causal relations consists in pointing out the Agonist and the Antagonist's tendencies to motion or rest indicated by the predicates to demonstrate how these entities interact and contribute to the formation of causal relations. The criteria for identifying the tendencies are semantic and oppositional. According to the semantic criterion, the tendency to motion is designated by the verbs with the meaning of force: the two traditional classes of causative verbs - lexical, e.g. pull, push, kill, break, etc., and periphrastic, e.g. make, have, get, force, let, cause (Shibatani 1976: 3). Secondly, the tendency to motion is implied in the meaning of experiential verbs by the semantic features denoting cause and/or motion in their dictionary definitions, e.g. want, wish, frighten, amuse, ask, say, speak, etc., and in a range of benefactive verbs denoting processes, e.g. gain, lose, win, and actions, e.g. supply, help, etc. (Cook 1979: 64). I include here the verbs having a causative semantic feature in their dictionary definitions, e.g. the verb suggest implies a tendency to motion implying compulsion due to the semantic feature 'make' in its meaning - "to make someone think that a particular thing is true" (Longman dictionary, online).

Example 3 demonstrates the Agonist's inclination to rest verbalised by the predicative are limited, and the Antagonist's tendency to motion is designated by the predicate has hugely expanded:

(3) Although a growing educated population in Asia and Latin America has hugely expanded the pool of qualified applicants, skilled migrants are limited to only one-third of the roughly 400,000 permanent-resident green cards handed out every year. (Newsweek, 10 April 2011) 
Finally, the tendency to motion is signalled by the verbs of motion, e.g. move, with subclasses indicating various aspects of moving such as direction, e.g. go, come, head for, manner of movement, e.g. rotate, stir, etc. The tendency to rest is indicated by the semantics of inactivity of the state verb be, e.g. to be dead, and verbs indicating the absence of motion, e.g. sit, stand, lie, stay.

According to the oppositional criterion, negation no/not signals the opposite tendency that the predicate conveys. In Example 4, the predicate has made with the object no decision represents the tendency to rest:

Though President Obama has made no decision about the way forward, some suggest that as many as 80,000 more could be sent in as reinforcements. (Newsweek, 6 November 2009)

During the third - differentiating - stage of the analysis of constructions, I analyse the semantics of prepositions and conjunctions rendering causal relations to demarcate reason, concession, purpose and result. I single out connectors with prototypical meanings, e.g. because expressing reason and though designating concession, and polysemantic conjunctions with several meanings, e.g. even if, as, while.

To conclude, causal relations are based on the opposition of two forces - the Agonist as a focal force and the Antagonist directed against it, characterised by opposite internal tendencies towards motion or rest. This cognitive background of causal relations can account for the peculiarities of their use in the articles of journalists of different age.

\section{Results and discussion}

In this study, the adverbials and clauses of reason, concession, purpose and result are analysed for their frequency in the articles by journalists of different age groups. The results show that in young reporters' texts causal relations are scarce; middle-aged authors' articles demonstrate a 17-per-cent-higher frequency of reason constructions as compared with the young reporters' texts, and in older journalists' news stories the occurrence of concessive relations rises by twelve per cent as compared to the middle-aged. For illustrating these findings, let us consider how Newsweek's authors of various age cover President Trump's announcement of his intention to declare a national emergency and build the U.S.-Mexico border wall. Trump's original message at the White House is quoted in (5):

"We can call a national emergency because of the security of our country, absolutely". (twitter.com, 4 January 2019) 
In this statement, Trump employs the adverbial of reason because of the security of our country to justify his actions on the U.S.-Mexico border. From the force-dynamic perspective, Trump positions his administration and himself as an Agonist by the pronoun we with the inclination to motion designated by the predicate can call. However, as the adverbial shows, the Agonist's motion is compelled by outer circumstances - America's national security induces his action. In terms of force dynamics, this utterance incorporates Langacker's billiard ball model with one moving entity, causing the other to move (Langacker 2008: 103).

In the news stories featuring this event, Trump's adverbial of reason is omitted or replaced by purpose relations by young reporters, reinterpreted in reason clauses by middle-aged authors and ousted by concessive clauses by older journalists.

\subsection{Young journalists' articles: Low frequency of causal relations}

In young authors' articles following Trump's announcement, the adverbial of reason because of the security of our country is omitted or replaced by purpose relations. Examples 6 and 7 have adverbials of purpose to secure funding for the border wall and in order to divert federal funds toward his long-promised border wall between the U.S. and Mexico, which refer to maintaining America's national security replacing the adverbial of reason in Trump's speech.

(6) Earlier this week during a press conference, Trump said he considered calling a national emergency to secure funding for the border wall. (Newsweek, 8 January 2019)

(7) As the government remains in limbo amid a battle over border security, Donald Trump has said he may declare a national emergency in order to divert federal funds toward his long-promised border wall between the U.S. and Mexico. (Newsweek, 7 January 2019)

(8) As the government enters its third week of the partial government shutdown, Trump said he would prefer to negotiate an agreement than to call a national emergency. (Newsweek, 8 January 2019)

Causal relations are omitted in Example 8, and the president's idea is reported in object clauses in (7) and (8) by the phrase call/declare a national emergency. Referring to the U.S. security, young journalists use the noun border in bold type in (6), (7) and (8), phrases border wall in (6), and border wall between the U.S. and Mexico in (7) as complements of verbs fund for and promise. Since these verbs have no force-dynamic features in their meanings, i.e. exertion of force 
and resistance to it (Talmy 2000: 409), no causal relations are involved in these fragments.

Young authors' tendency to use causal relations scarcely manifests itself throughout the whole corpus of 90 analysed texts. The analysis of causal constructions with spatial and temporal adverbials prompts that young reporters focus more on spatial and temporal relations than the journalists of other age groups. The data is presented in Tables 1 and 2.

\begin{tabular}{|l|c|c|c|}
\hline Relations & $\begin{array}{c}\text { Young } \\
\text { authors }\end{array}$ & $\begin{array}{c}\text { Middle-aged } \\
\text { authors }\end{array}$ & $\begin{array}{c}\text { Older } \\
\text { authors }\end{array}$ \\
\hline Spatial & 398 & 296 & 297 \\
\hline Temporal & 831 & 774 & 698 \\
\hline Total & $\mathbf{1 , 2 2 9}$ & $\mathbf{1 , 0 7 0}$ & $\mathbf{9 9 4}$ \\
\hline
\end{tabular}

Table 1: The frequency of spatial and temporal relations

\begin{tabular}{|l|c|c|c|}
\hline Causal relations & $\begin{array}{c}\text { Young } \\
\text { authors }\end{array}$ & $\begin{array}{c}\text { Middle-aged } \\
\text { authors }\end{array}$ & $\begin{array}{c}\text { Older } \\
\text { authors }\end{array}$ \\
\hline Relations of reason & 58 & 93 & 67 \\
\hline Relations of concession & 48 & 49 & 68 \\
\hline Relations of purpose & 74 & 73 & 60 \\
\hline Relations of result & 22 & 25 & 29 \\
\hline Total & $\mathbf{2 0 2}$ & $\mathbf{2 4 0}$ & $\mathbf{2 2 3}$ \\
\hline
\end{tabular}

Table 2: The frequency of causal relations

Spatio-temporal relations dominating in young reporters' articles are more basic from the cognitive point of view since they locate the referents in time and place and establish priority and sequence of events happening and map them on the timeline. These relations involve no force dynamics as the time of events is majorly described as a point or duration or an interval's length; the spatial locating of referents presupposes stating the place or path of motion or direction. While spatial and temporal relations are crucial to news discourse, as every story is temporally organised and orients the readers in places, these relations are more frequent in young authors' articles. Such use is explained by the fact that young 
reporters tend to focus on the spatial and temporal grounding of events, which is the basis from where we reason about other relations. As causal relations are more complex than spatio-temporal due to the force-dynamic cognitive background, their rising frequency with authors' age reveals more elaborated patterns of thought and reasoning.

With less attention to causal relations in total, as Table 2 suggests, young journalists use purpose constructions more often than other types. It may indicate young people's tendency to be focused on plans, intentions and future accomplishments (Erikson \& Erikson 1998: 197).

So, while reporting events, young authors locate referents in space and time and in terms of causal relations they state purposes. Middle-aged and older authors report events using more causal relations considered further.

\subsection{Middle-aged journalists' articles: Domination of reason relations}

In the texts of the middle-aged journalists, adverbial clauses of reason replace Trump's adverbial in (5). Examples 9 and 10 are taken from the articles featuring the president's announcement about the border wall and have adverbial clauses of reason introduced by the conjunction because:

(9) Trump is desperately pushing for the border wall because that "particular big lie" was at the centre of his own 2016 presidential campaign. (Newsweek, 7 January 2019)

(10) He [Trump] claimed that the border wall would pay for itself because the cost of illegal drugs exceeds $\$ 500$ billion a year. (Newsweek, 9 January 2019)

Comparing these sentences with Trump's original message, the president is similarly portrayed in all the statements as an Agonist with a tendency to motion signalled by the predicates is pushing in (9) and claimed in (10). His motion is accelerated by the phrases big lie and the cost of illegal drugs that, according to Langacker (Langacker 2008: 103), like billiard balls cause Trump to act.

Middle-aged authors' articles, in general, demonstrate a 17-per-cent-higher frequency of reason relations as compared with the texts of young reporters; in the articles of older journalists the occurrence of adverbials and clauses of reason declines, as Table 3 suggests: 


\begin{tabular}{|l|c|c|c|}
\hline Relations of reason & $\begin{array}{c}\text { Young } \\
\text { authors }\end{array}$ & $\begin{array}{c}\text { Middle-aged } \\
\text { authors }\end{array}$ & $\begin{array}{c}\text { Older } \\
\text { authors }\end{array}$ \\
\hline Adverbial modifiers & 22 & 29 & 26 \\
\hline Adverbial clauses & 36 & 64 & 41 \\
\hline Total (218) & $\mathbf{5 8}$ & $\mathbf{9 3}$ & $\mathbf{6 7}$ \\
\hline
\end{tabular}

Table 3: The frequency of adverbials and clauses of reason

The domination of reason relations in the texts of middle-aged authors proves more attention in this age to various reasons for events. In the news, the journalists employ two force-dynamic models of reason which I call 'energy transfer' and 'energy loss models'. In the first model exemplified above in (5), (9) and (10), the energy of one entity is transmitted to another, causing it to move. The other model - energy loss - demonstrates how inactivity of one entity is due to blocking the activity of the other (Potapenko 2016: 18). Reason relations in Examples 5, 9 and 10 are based on the energy transfer model, and Example 11 illustrates energy loss:

(11) In all likelihood, he was flagged for a Visas Mantis review, because of his training in electrical engineering. (Newsweek, 16 March 2009)

In Example 11, a man applying for a visa to the U.S. is the Agonist named by the pronoun he; his inactivity is indicated by the predicate was flagged. The adverbial of reason his training in electrical engineering indicates blockage - he was denied the visa, i.e. the energy is lost.

Both energy transfer and energy loss models explain the use of adverbials and clauses of reason dominating in middle-aged authors' articles. This prevalence exemplified in Table 3 indicates that people of this age are more likely to pay attention to the reasons that bring something about. The decline in the frequency of reason relations in older age is explained by their ousting by concessives discussed further.

\subsection{Older journalists' articles: Domination of concessive relations}

In the articles of older authors, the president's idea of national security is represented more often by concessive clauses. As Example 12 demonstrates, older journalists do not see Trump as an Agonist with a tendency to motion as the middle-aged do and Trump himself claims. Instead, older authors portray him as an Antagonist with a tendency to rest signalled by the predicate has made no 
decision, while the lawyers in the White House Counsel's Office are Agonists with a propensity to motion indicated by the predicate are working:

Although Trump has made "no decision" about a declaration, Pence said, lawyers in the White House Counsel's Office are working to determine the president's options and prepare for any possible legal obstacles. (Newsweek, 8 January 2019)

Instead of billiard ball model of causal relations exemplified in (9) and (10), which appeared typical of middle-aged journalists' discourse, concessive clauses prevailing in older authors' articles reveal the participants - the Agonist and the Antagonist - with the opposite tendencies to motion and rest. As Example 12 shows, Trump's rest, i.e. making no decision, is in opposition to the lawyers' motion, i.e. working.

In (13) below, older journalists position Trump as an Agonist with a tendency to motion signalled by the predicate declare; however, this motion is shown as slight due to the modal could. Since the modal can indicates possibility (Ruppenhofer \& Rehbein 2012: 1542), it shows not the Agonist's motion, but rather setting to motion or planning action:

Trump said on Friday he could declare a national emergency to circumvent lawmakers and build the wall, though budget experts said Congress would still need to allocate the funds. (Newsweek, 8 January 2019)

As for the reason relations in older authors' articles, they become more complicated, since they state two reasons in one sentence or have one more reason implied. As Example 14 demonstrates, the phrase in part standing before the conjunction because implies that there are other reasons apart from those suggested in this clause:

(14) Trump would be poorly positioned to defend such an action in federal courts, in part because his statements about the wall have been contradictory and have contained provable falsehoods. (Newsweek, 8 Janaury 2019)

The total frequency of concessive relations rises in the articles of older journalists by twelve per cent as compared to the middle-aged, as Table 4 below suggests: 


\begin{tabular}{|l|c|c|c|}
\hline $\begin{array}{l}\text { Relations } \\
\text { of concession }\end{array}$ & $\begin{array}{c}\text { Young } \\
\text { authors }\end{array}$ & $\begin{array}{c}\text { Middle-aged } \\
\text { authors }\end{array}$ & $\begin{array}{c}\text { Older } \\
\text { authors }\end{array}$ \\
\hline Adverbial modifiers & 18 & 17 & 21 \\
\hline Adverbial clauses & 30 & 32 & 47 \\
\hline Total (164) & $\mathbf{4 8}$ & $\mathbf{4 9}$ & $\mathbf{6 8}$ \\
\hline
\end{tabular}

Table 4: The frequency of adverbials and clauses of concession

While concessive adverbials reveal equal distribution in the articles of all age groups ranging from 18 to 21 according to Table 4, concessive clauses reflect authors' age in two ways - first, in terms of overall frequency, and secondly, in the use of conjunctions of varying concessive semantics.

As for the overall frequency, concessive clauses dominate in the articles of older journalists - the data presented in Table 4 above reveals a steady increase from 30 clauses in young reporters' texts to 46 in those of older journalists. Since cognitively, concessive relations rest on the experience of colliding with a barrier and overcoming its resistance (Talmy 2000: 415), the rise in concessive clauses in the articles of older journalists testifies to their experience in tackling problems and hardships. In concessive clauses, an obstacle is presented as the Antagonist which hampers the Agonist's inclination to motion or to rest. In its turn, the Agonist as a focal force overcomes the Antagonist's resistance. Taking into account the opposite tendencies of the Agonist and the Antagonist, I distinguish two cognitive models of verbalising concession - the static concessive model and the dynamic concessive model that are extensively elaborated in the articles of older journalists:

Localisation usually trumps globalisation, though countries seem to succeed more when they encourage globalisation. (Newsweek, 25 July 2009)

In Example 15, concessive relation between the main and the adverbial clause is based on the dynamic model: the Agonist named in the main clause by the noun localisation tends motion indicated by the verb trumps; the Antagonist designated by the noun globalisation reveals the inclination to rest due to the semantics of the predicate trump - 'to beat somebody in a competitive situation' (Longman dictionary, online). In opposition to these forces, the Agonist localisation - is more potent because, given the state borders, localisation appears more prominent.

As for the concessive conjunctions, they render varying ways of overcoming obstacles. As Table 5 suggests, young journalists use the prototypical conjunction 
though most often. With age, authors utilise a greater variety of conjunctions: temporal concessive (while, whereas, even as, even when), comparative concessive (as), alternative concessive (whether ... or ...), conditional concessive (if, even if) and generalising concessive (whatever, whoever, however, whenever and the equivalents no matter what/who/how).

\begin{tabular}{|c|c|c|c|}
\hline $\begin{array}{l}\text { Semantics } \\
\text { of conjunctions }\end{array}$ & $\begin{array}{c}\text { Young } \\
\text { authors }\end{array}$ & $\begin{array}{l}\text { Middle-aged } \\
\text { authors }\end{array}$ & $\begin{array}{c}\text { Older } \\
\text { authors }\end{array}$ \\
\hline Prototypical & 15 & 15 & 20 \\
\hline though & 14 & 15 & 19 \\
\hline despite the fact that & 1 & - & 1 \\
\hline Marginal & 15 & 17 & 26 \\
\hline $\begin{array}{l}\text { temporal concessive: } \\
\text { simultaneity while } \\
\text { consecutiveness even } \\
\text { as, even when }\end{array}$ & $\begin{array}{l}4 \\
4\end{array}$ & $\begin{array}{l}4 \\
3\end{array}$ & $\begin{array}{l}8 \\
4\end{array}$ \\
\hline $\begin{array}{l}\text { comparative } \\
\text { concessive as }\end{array}$ & 2 & 2 & 1 \\
\hline $\begin{array}{l}\text { alternative } \\
\text { concessive } \\
\text { whether...or... }\end{array}$ & 2 & 4 & 1 \\
\hline $\begin{array}{l}\text { conditional } \\
\text { concessive if, even if }\end{array}$ & 1 & 2 & 4 \\
\hline $\begin{array}{l}\text { generalising } \\
\text { concessive however, } \\
\text { whoever/no matter } \\
\text { how }\end{array}$ & 2 & 2 & 8 \\
\hline Total & 30 & 32 & 46 \\
\hline
\end{tabular}

Table 5: The semantics of concessive conjunctions

Temporal concessive conjunctions introduce clauses locating obstacles in time and may imply simultaneity of Agonist and Antagonist's force exertion signalled by the conjunction while and consecutiveness of their activity designated by even as, even when. In (16), the process of amassing money from 6,500 to 11,205 named metaphorically by the noun ride face some hardships - bumps: 
(16) While there were bumps along the way, the ride from 6,500 to 11,205 was generally smooth and steady. (Newsweek, 7 June 2010)

Comparative concessive conjunction as introduces clauses foregrounding information supporting the authors' position on the reported events and background other views or evidence which may not support his ideas, while still acknowledging these views. In (17) due to the initial position of the concessive clause Shocking as it sounds the word shocking is in the focus of the author's attention:

(17) Shocking as it sounds, failure can be a good thing. (Newsweek, 20 September 2010)

From the force-dynamic perspective, two opinions clash in Example 17 - the noun failure has a negative connotation due to the semantic feature 'bad' in its meaning (Merriam-Webster, online), and the evaluative adjective good conveys positive connotation.

Alternative concessive conjunction whether...or... focuses on two or even three obstacles at once, since it is a double conjunction opening a clause with two options or alternatives (Cambridge dictionary, online). Example 18 from an older author's article denotes two obstacles that a senator (the Agonist) has to deal with - conservatives (the Antagonist- ${ }_{1}$ ) and ethics rules (the Antagonist- ${ }_{2}$ ):

Whether the explanation is conservatives who are terrified that smiling at a liberal will bring a primary challenge from an unhinged tea-bagger, or the unintended consequences of ethics rules limiting convivial junkets, it's on many a senator's mind: the place is broken. (Newsweek, 18 January 2010)

Conditional concessive conjunctions even if meaning 'whether or not' is mainly used to talk about imaginary situations:

Changing the alphabet has meant that Turks can read, even if it is only the football results. (Newsweek, 28 February 2011)

Generalising concessive conjunctions whatever, however, whoever/no matter how, etc. imply that what exactly happens is not important because it does not make any difference to a described situation or that the reporter does not mind which thing is chosen. In (20) the subject politicians enacts the role of the Agonist with a propensity to motion designated by the predicate would do, and the generalising concessive clause Whatever the leaked material suggests implies that who the Antagonist is does not make any difference - the Agonist realises his tendency to motion in any case: 
Whatever the leaked material suggests, the politicians would do well to apologise. (Newsweek, 20 December 2010)

There are at least two implications for strong dominance of generalising concessive clauses in the articles by older journalists - first, at this age, they have a richer experience in overcoming different obstacles, solving problems and making decisions, and secondly, older authors may be reluctant to specify the obstacles and generalise the information about them. Generally, the findings suggest that with age journalists become focused on several obstacles at once, they classify them, generalise, compare and locate in time, which testifies to a more sophisticated understanding of causal relations.

\section{Conclusions}

This study has found that age influences the linguistic representation of cause in English news magazine articles in two ways. First, it determines the frequency of causal relations in the articles of young, middle-aged and older authors; secondly, it accounts for the dominant types of causal relations in the texts written by authors of different age. In the texts of young reporters, causal relations are scarce, since people of this age focus more on spatial and temporal localisations of events. Unlike them, middle-aged authors' articles demonstrate a 17-per-centhigher frequency of adverbials and clauses of reason grounded in energy transfer model with one moving entity causing another to move, and energy loss model where inactivity of one entity is due to blocking of the other entity. It indicates more attention at this age to various causes of events. In older authors' articles, causal relations are represented by concessive clauses whose occurrence rises by twelve per cent. They are introduced by a range of conjunctions specifying concessive meaning: temporal concessive, comparative concessive, alternative concessive, conditional concessive and generalising concessive.

This study is promising because further investigations of speakers' parameters such as gender, social background etc. may pave the way for a theory that accounts for the usage of causal relations by individual speakers and cohorts. This study may also be extended to other discourse types, primarily to explore oral communication - public speeches, where causal relations serve to secure argumentation and everyday dialogues, where they are employed to convey opinions, judgments and evaluations.

\section{References}

Cambridge Dictionary Online. https://www.dictionary.cambridge.org 
Chu, C. (2004) Event Conceptualisation and Grammatical Realisation: The Case of Motion in Mandarin Chinese. PhD Dissertation. Manoa: University of Hawaii.

Cook, W. H. (1979) A Grammar of North Carolina Cherokee. PhD Dissertation. New Haven: Yale University.

Cotter, C. (2010) News Talk: Investigating the Language of Journalism. Cambridge: Cambridge University Press.

Copley, B., Wolff, P. and Shepard, J. (2015) 'Force interaction in the expression of causation.' Proceedings of SALT 25, 433-451.

Copley, B. and Harley, H. (2015) 'A force-theoretic framework for event structure.' Linguistics and Philosophy 38(2), 103-158.

Croft, W. (2012) Verbs: Aspect and Causal Structure. Oxford: Oxford University Press.

Dalbergenova, L., Zharkynbekova, S., Akynova, D. and Aimoldina, A. (2014) 'Cognitive approach to the study of causal relations.' Procedia - Social and Behavioral Sciences $143,233-237$.

Erikson, E. H. and Erikson, J. M. (1998) The Life Cycle Completed: Extended Version. New York: W. W. Norton.

Fillmore, C. J. (1977) 'The case for case reopened.' In: Cole, P. and Sadock, J. (eds) Syntax and Semantics. Volume 8: Grammatical Relations. New York: Academic Press. 59-82.

Gilquin, G. (2010) Corpus, Cognition and Causative Constructions. Amsterdam and Philadelphia: John Benjamins.

Goldberg, A. E. (2010) 'Verbs, constructions, and semantic frames.' In: Rappaport Hovav M., Doron, E. and Sichel, I. (eds) Lexical Semantics, Syntax, and Event Structure. Oxford: Oxford University Press. 39-58.

Heil, J. (2016) 'Causal relations.' In: Marmodoro, A. and Yates, D. (eds) The Metaphysics of Relations. Oxford: Oxford University Press. 127-137.

Hollenbach, B. (1975) 'Discourse structure, interpropositional relations, and translation.' Notes on Translation 1(56), 2-21.

Kemmer, S. and Verhagen, A. (1994) 'The grammar of causatives and the conceptual structure of events.' Cognitive Linguistics 5(2), 115-156.

Lakoff, G. and Johnson, M. (1980) Metaphors We Live by. Chicago: University of Chicago Press.

Langacker, R. W. (2008) Cognitive Grammar. A Basic Introduction. Oxford: Oxford University Press.

Levin, B. and Rappaport Hovav, M. (1995) Unaccusativity. Cambridge, MA: MIT Press.

Longman Dictionary of Contemporary English Online. https://www.ldoceonline.com

Martin, F. and Schafer, F. (2014) 'Causation at the syntax-semantics interface.' In: Copley, B. and Martin, F. (eds) Causation in Grammatical Structures. Oxford: Oxford University Press. 209-244.

Merriam-Webster Dictionary Online. https:/www.merriam-webster.com/dictionary

Neeleman, A. and van de Koot, H. (2012) 'The linguistic expression of causation.' In: Everaert, M., Marelj, M. and Siloni, T. (eds) The Theta System. Oxford: Oxford University Press. 20-51.

Pander Maat, H. and Degand, L. (2001) 'Scaling causal relations and connectives in terms of speaker involvement.' Cognitive Linguistics 12(3), 211-245.

Pander Maat, H. and Sanders, T. (2001) 'Subjectivity in causal connectives: An empirical study of language in use.' Cognitive Linguistics 12(3), 247-273.

Potapenko, S. (2016) 'Cognitive rhetoric of effect: Energy flow as a means of persuasion in inaugurals.' Topics in Linguistics 17(2), 12-25. 
Quirk, R., Greenbaum, S., Leech, G. and Svartvik, J. (1985) A Comprehensive Grammar of the English Language. London: Pearson Longman.

Ruppenhofer, J. and Rehbein, I. (2012) 'Yes we can!? Annotating the senses of English modal verbs.' LREC 2012, Eighth International Conference on Language Resources and Evaluation - European Language Resources Association, 1538-1545.

Shibatani, M. (1976) 'The grammar of causative constructions: A conspectus.' In: Shibatani, M. (ed.) Syntax and Semantics. Volume 6: The Grammar of Causative Constructions. New York: Academic Press. 1-40.

Sweetser, E. (1990) From Etymology to Pragmatics. Cambridge: Cambridge University Press.

Solstad T. and Bott O. (2017) 'Causality and causal reasoning in natural language.' In: Waldmann, M. R. (ed.) The Oxford Handbook of Causal Reasoning. New York: Oxford University Press. 619-644.

Talmy, L. (1985) 'Force dynamics in language and thought.' Papers from the Parasession on Causatives and Agentivity at the Twenty-first Regional Meeting of the Chicago Linguistic Society 21, 293-337.

Talmy, L. (2000) Toward a Cognitive Semantics. Volume 1: Concept Structuring Systems. Cambridge: The MIT Press.

Williams, B. (1979) 'Internal and external reasons.' In: Harrison, R. (ed.) Rational Action. Cambridge University Press. 101-113.

Wolff, P., Jeon, G.-H., Klettke, B. and Yu, L. (2010). 'Force creation and possible causers across languages.' In: Malt, B. C. and Wolff, P. (eds) Words and the Mind: How Words Capture Human Experience. Oxford: Oxford University Press. 93-110.

\section{Sources:}

Facebook. https://www.facebook.com Instagram. https://www.instagram.com LinkedIn. https://www.linkedin.com Newsweek. https://www.newsweek.com Newsweek people. https://en.wikipedia.org/wiki/Category:Newsweek_people

Iryna Danylchenko is Associate Professor of Linguistics at Nikolai Gogol State University of Nizhyn, Ukraine. She specialises in cognitive linguistics, discourse and identity. Her research interests concern how authors' identities are revealed in discourse and mark the style. Her current research focuses on media discourse, specifically how journalists' age influences the linguistic representation of causal relations in English news magazine articles. She is presently involved in a study of cognitive and rhetorical aspects of language use. Her works have appeared in Odessa Linguistic Journal, and Linguistic \& Rhetorical Paradigm: Theoretical and Applied Aspects and other journals.

Address: Iryna Danylchenko, PhD., Germanic Philology Department, Foreign Languages Faculty, Nikolai Gogol State University of Nizhyn, 2 Grafska Str., Nizhyn, Chernihivska Oblast, Ukraine, 16600. [e-mail: iryna.danylchenko@, ndu.edu.ua ] 